Vaibhav Bhat, Jyoti Snehal Trivedi, Bhargav Dave (2018). "Improving Design Coordination with Lean and BIM an Indian Case Study." In: Proc. $26^{\text {th }}$ Annual Conference of the International. Group for Lean Construction (IGLC), González, V.A. (ed.), Chennai, India, pp. 1206-1216. DOI: doi.org/10.24928/2018/0479. Available at: www.iglc.net

\title{
IMPROVING DESIGN COORDINATION WITH LEAN AND BIM, AN INDIAN CASE STUDY
}

\author{
Vaibhav Bhat ${ }^{1}$, Jyoti Snehal Trivedi², Bhargav Dave ${ }^{3}$
}

\begin{abstract}
Building Information Modeling (BIM) and Lean construction principles have been used independently as significant methods to construction process improvement. Their combination presents challenges and opportunities in implementation, especially when applied in the field.

This study explores two perspectives, firstly identifying factors and issues in design coordination of construction projects; secondly, applying lean and BIM functions simultaneously to overcome some of the problems in design coordination. Relative Importance Index (RII) method was adopted to identify major critical factors of design coordination and their effect on the three categories viz; design management, time management and cost management. Subsequently, BIM and lean functions such as 4D simulation integrated with Look ahead planning, Quantity take off, Clash detection during look-ahead and weekly work planning, to reduce change orders and RFIs for additional value to customer were applied in an integrated fashion. This improvised BIMLean process facilitates the design co-ordination during construction phase for all project stakeholders. Finally a matrix is drafted based on previous research that shows integration of Lean Principles and BIM functionalities adopted for the case study.
\end{abstract}

\section{KEYWORDS}

Lean construction, Building Information Modelling (BIM), Request for Information (RFI), Clash Detection, 4D Scheduling

\section{INTRODUCTION}

The design phase for any project is characterized by high level of uncertainties in resulting outputs in contrast with design requirements. The problems occurs when the requirements and the resulting outputs both are indistinct. (Maier and Storrle, 2011). BIM

1 Masters Student, Centre for Environment Planning and Technology, Ahmedabad: India Phone +91 9818442856;vaibhav.bhat.mtech16@cept.ac.in

2 Assistant Professor, Centre for Environment Planning and Technology, Ahmedabad: India Phone 07926302470-311;jyoti@cept.ac.in

3 Research Fellow, School of the Built Environment, University of Salford; UK. Phone +44 161 2953431; B.Dave@salford.ac.uk 
(Building Information Modelling) and Lean are the two different intellects that are having an influence on the construction industry. Lean is a concept related to production process while BIM is rooted in technology that instead of acting as standalone systems, when mutually applied to the construction projects helps to achieve great results that solves many of the issues prevailing in the construction projects (Sacks et.al, 2010).

Each project involves different stakeholders having their own and joint responsibilities. The process involves detailed inputs from each stakeholder for different building systems complying with norms (Tatum and Korman, 2000). Inadequate coordination gets reflected in form of waste for the projects in terms of design, cost and time. Instead of focusing on value addition, time is spent on resolving coordination issues (Tribelsky and Sacks, 2011). Moreover, communication through 2D information limits the ability of different stakeholders to coordinate, which in turn effects communication during meetings (Fischer et al., 2002).

BIM tools have had a noteworthy impact on effectiveness of the coordination process. Studies reflect the prised and numerous use of BIM for design coordination and conflict detection (Bernstein and Jones, 2012, Eastman et al, 2008). However, research has shown that implementing BIM alone as a technological solution has a limited benefit. To this end, the synergy between BIM and Lean show that many of the design coordination issues identified by previous research can be tackled through simultaneous implementation of these two concepts (Sacks et.al, 2010). This paper attempts to first identify coordination issues in Indian construction projects and subsequently tries to implement integrated lean and BIM tools to overcome these issues.

In this case study BIM was applied in order to improve design coordination between different design disciplines. Model checking was used to control clashes at the time of execution. Moreover the methodology was also implemented to create a 4D BIM that showed the simulation of the construction process over time. 4D BIM allowed the analysis of the proposed design and its constructability that is going to be executed.

The paper is structured as follows: first section outlines main problems with design coordination in construction and their probable solutions found in literature. Second part outlines the problems in design coordination in Indian construction projects through interviews. The next section covers a case study where integrated lean and BIM functions are deployed in terms of: Quantification, Clash detection, Cost Variation, Look ahead and 4D Simulation. Finally, discussion and conclusion are provided along with suggestions for future research. This strategy of design coordination focuses on interaction subtleties and information dispersal to support design teams in improving design course, knowledge change, and value creation while reducing wastes.

\section{LITERATURE REVIEW}

Previous research in design coordination has classified design issues in three main categories: design criteria, construction, and operations issues (Korman et.al, 2003), further, the issues were sub-classified into conceptual reasoning and spatial aspects. Also, constraints were identified with underlying reasons for each discipline. (Tabesh and 
Staub-French 2006). According to Mehrbod (2015), the issues in design coordination that can be traced are illogical design, multiple systems conflict, trades design conflict and incorrect design details. The most essential design defects identified by Mardones and Alarcon (1998) were: lack of information and wrong information Wang and Leite (2014) argue that the coordination issues emerge due clashes related to Architectural, Structural and MEP designs, which remain undetected during the design stage. While BIM may help resolve clashes through clash detection, the process needs to be managed effectively in order to be effective. This is highlighted by Tauriainen et, al. (2016) who highlighted coordination issues in design as indistinct sharing of duties between designers in the team, lack of communication, insufficient BIM knowledge of design manager, modelling instructions not used for project, compressed design schedule, conflicts between models, frequent changes during design, and no clear scope. Pikas et, al. (2015) mention that delivering better products is the primary aim for design management in a research that identified typical design management inadequacies and possible remedies. The issues determined were variability in projects, poor planning and avoidance of iterations, poor specification of clients, and poor integration of design disciplines.

It emerges that the coordination aspects along with communication and process management are equally (or more) important than the technological solutions (such as BIM) alone. This is highlighted by a study based on ethnographic action research, which suggested that adopting lean practices reduces coordination related issues at the time of execution and paves the path for BIM adoption (Mahalingam et.al 2015).

Literature explains that the key sources of design error are connected to repetitive design cycles that results from unanticipated changes, poor management and communication (Arayici et.al, 2012, Hattab et.al, 2016) disrupt design workflow, subsequently creating waste such as increased cycle times, cost, rework, and errors. Design clashes involves positioning errors where building components intersect each other when the models are fused. To prevent costly rework, resolution of these clashes is important (J.Won et.al, 2016). Recent research conducted by Peansupap and Ly (2015) studied five categories of structural and MEP related design errors but the study was limited to schedule delays and omitted any discussion on how BIM can facilitate error mitigation at the design stages. Research that studied design clashes are grounded on limited scope of analysis.

The above highlights major design coordination issues and helps classify them in different categories and provides underlying reasons behind issues. Lean and BIM solutions can help overcome many of these issues as highlighted by several studies (Sacks et al. 2010; Rischmoller, Alarcón, and Koskela 2006), however not much has been reported on solving design coordination issues through lean and BIM integration on realworld projects.

\section{PRELIMINARY STUDY}

The initial part of the preliminary study was based on a questionnaire survey that was divided into several parts: Questions were about the frequency of coordination issues, impact of issues on cost and time, knowledge on concepts of Lean and BIM and these 
questions were mostly ranking based that helped to get the major critical issues. Further factors were categorized into its impact on design management, cost management and time management.

The data received in the questionnaire survey was from 11 respondents across India (Ahmedabad, New Delhi) whose profiles are: A-Proprietor, B-Senior Manager, C-Project Coordinator, D, F, H-Director, E-Executive Architect, G-Site Engineer, I, J, K-Project Manager.

The data received was analysed by Relative Importance Index (RII) method to determine the relative importance of the issues/factors in design coordination identified by the survey. Some questions were framed to capture background information of the respondents.

The frequency for the questions was measured on the scale of 1 to 5 in which $1=$ Never and $5=$ Very frequent. The respondents helped in addressing the majority of design coordination issues happening on site during execution and also contributing their knowledge regarding BIM and Lean. The major critical factors of project coordination issues is mentioned in the below Table 1 .

The issues that were found in literature resonated well with those found during the site visit and questionnaire survey.

Table 1 - Categorized factors of project coordination issues

\begin{tabular}{|c|c|c|c|}
\hline Sr.No. & Issues & Rank & Category \\
\hline 1. & Delayed decisions & 1. & Design \\
\hline 2. & Changes in drawing & 2. & Design \\
\hline 3. & Issue of RFI and Change orders & 3. & Design \\
\hline 4. & Clients requirements changed and caused redesign & 4. & Time \\
\hline 5. & $\begin{array}{l}\text { Waiting for others to complete their works before the proceeding } \\
\text { works can be carried out. }\end{array}$ & 5. & Time \\
\hline 6. & Time in supervising and inspecting the construction work & 6. & Time \\
\hline 7. & $\begin{array}{l}\text { Time for instructions and communication among different tiers and } \\
\text { trades of workers }\end{array}$ & 7. & Time \\
\hline 8. & Changes in input data caused redesign in building services design & 8. & Cost \\
\hline 9. & Waiting for the clarification on the site due to changes in drawings & 9. & Cost \\
\hline
\end{tabular}

\section{CASE STUDY}

A case study project an IT park in Gurgaon (Haryana) India, was undertaken to study issues regarding design coordination, and apply Lean and BIM solution to try to solve them. The case study was carried over a 2 month period and the issues related to design coordination were studied. Total site area was 100,362 sq. There were total of 9 towers in the complex out of which 5 were already constructed and 4 were under construction. The scope for study was limited to Tower 9 only. Several topics were addressed in design coordination as mentioned in Table 2 . The current scenario of the case study related to pre-implementation of Lean and BIM process is explained in Table 8.

Table 2 - Key topics addressed by the case study 


\begin{tabular}{lll}
\hline 1.1 Clash Detection & 2.1 One month Look ahead & 3.1 Design changes impact \\
& schedule & on Cost-MEP and Structure \\
1.2 Quantity take-off & 2.2 4D Simulation & 3.2 Extra work \\
$\begin{array}{c}\text { 1.3 RFI(Request for } \\
\text { information) }\end{array}$ & 2.3 Quantity Take-off- & 3.3 Quantity Take-off \\
$\begin{array}{l}\text { 1.4 Quantity variation with } \\
\begin{array}{l}\text { respect to BOQ(Bill Of } \\
\text { Quantities }\end{array}\end{array}$ & 2.4 Look ahead planning & 3.4 Variations in Quantity \\
\hline
\end{tabular}

\section{METHOD}

\section{Quantification-Quantity Take-off from BIM}

Automated quantity take off is more precise as there are less chances of error, hence reducing variability and taking less time with respect to manual calculations. The quantities automatically change if at any time in future design changes. For the purpose of this case study, quantity take-off was taken up for Slab, Blockwork and Column as shown in Table 3 and Table 4.

Table 3-Quantity take off-Slab

\begin{tabular}{|c|c|c|c|}
\hline Description & $\mathrm{BOQ}$ & Revit & Manual \\
\hline $\begin{array}{l}\text { Typical (1st, 2nd, 3rd, 4th, 5th, 7th, 8th, } \\
\text { 9th ) }\end{array}$ & $2600 \mathrm{~m}^{3}$ & $2,703.00 \mathrm{~m}^{3}$ & $2,393.00 \mathrm{~m}^{3}$ \\
\hline Ground floor & $350 \mathrm{~m}^{3}$ & $339.00 \mathrm{~m}^{3}$ & $301.00 \mathrm{~m}^{3}$ \\
\hline \multicolumn{4}{|c|}{ Table 4-Quantity takeoff Blockwork } \\
\hline Description & $\overline{B O Q}$ & Revit & Manual \\
\hline $100 \mathrm{~mm}$ blockwor & $2,820.00 \mathrm{~m}^{2}$ & $1,829.00 \mathrm{~m}^{2}$ & $1,627.22 \mathrm{~m}^{2}$ \\
\hline 200mm blockwork: 100 Nos & $11,820.00 \mathrm{~m}^{2}$ & $10,091.00 \mathrm{~m}^{2}$ & $9,986.89 \mathrm{~m}^{2}$ \\
\hline
\end{tabular}

There were significant time savings compared to manual take off, as time consumed in BIM Quantity take-off was: 10-15 minutes, whereas for manual take-off it was: 2 hours. For the scope of the entire building the time saving was approximately $88 \%$. The benefits were not just limited to time saving, as the quantity difference between BOQ and BIM showed that, automated BIM based data take-off can reduce the gap of actual consumption vs planned during execution.

The variation in quantity and cost for the entire project was identified as: Blockwork (100 \& $200 \mathrm{~mm})-2,155$ sq.m, Rs $-28,17,800(\sim-43,062.84)$, Column concrete -175 cu.m , Rs -14,38,850 ( \$ -21,983.70) and Slab concrete 350 cu.m, Rs 24,51,750 $(\sim 37,511.78)$. This process helped at the time of billing by comparing and avoiding any discrepancies, hence reducing variability and improving the production and cost control.

\section{Clash Detection:}

Clash detection helps to track design coordination problems at an early stage. In this case clashes were detected by appending different models in Navisworks and the results were obtained in the form of reports that were resolved before execution started. The clashes were between two models; Model 1-Architecture/Structure and Model 2Electrical/Plumbing, where the clash report was generated first between Architecture (Wall/Blockwork) vs. Electrical (Lighting) and second between Structure (Wall/Blockwork) vs. Plumbing (Piping) as shown in Table 5. 
Table 5 Clash Detection (a subset is shown)

\begin{tabular}{ccccccc}
\hline $\begin{array}{c}\text { Clash } \\
\text { Type } \\
\text { clashes }\end{array}$ & $\begin{array}{c}\text { Number } \\
\text { of }\end{array}$ & Model 1 & Model 2 & $\begin{array}{c}\text { Primary } \\
\text { Responder }\end{array}$ & Reviewer & $\begin{array}{c}\text { Review } \\
\text { Status }\end{array}$ \\
\hline Real & 8 & $\begin{array}{c}\text { Architectural: } \\
\text { Wall; Blockwork } \\
200 \mathrm{~mm}\end{array}$ & $\begin{array}{c}\text { Electrical: } \\
\text { Lighting Fixtures }\end{array}$ & $\begin{array}{c}\text { BIM } \\
\text { coordinator }\end{array}$ & $\begin{array}{c}\text { Architect; } \\
\text { Electrical }\end{array}$ & Resolved \\
Real & 8 & $\begin{array}{c}\text { Structure; } \\
\text { Blockwork } 200 \\
\text { mm }\end{array}$ & $\begin{array}{c}\text { Plumbing: } \\
\text { Circular Pipe }\end{array}$ & $\begin{array}{c}\text { BIM } \\
\text { coordinator }\end{array}$ & $\begin{array}{c}\text { Structure: } \\
\text { Plumbing: }\end{array}$ & Resolved \\
Real & 8 & $\begin{array}{c}\text { Structure: } \\
\text { Column }\end{array}$ & $\begin{array}{c}\text { Plumbing: } \\
\text { Circular Pipe }\end{array}$ & $\begin{array}{c}\text { BIM } \\
\text { coordinator }\end{array}$ & $\begin{array}{c}\text { Structure: } \\
\text { Plumbing }\end{array}$ & Resolved \\
\hline
\end{tabular}

The clashes detected were mostly regarding MEP. The MEP pipes were clashing with blockwork and columns. The clashes regarding electrical design and architecture were due to fixtures and blockwork that were rectified by just shifting the lights away, but the MEP and Structure clashes were solved by getting detailed drawings and provision of sleeves at the time of designing. The clash detection helped in a way that it paved the path for solving the issues between plumbing and structure consultant in advance by sleeve provision.

But if this process would have not been followed, it would have caused an extra cost of Rs 61, $6400(\sim 9,449.41)$ for the entire scope and 1 week instead of a day for detecting clashes manually contributing to waste. The total number of real (solvable) clashes detected for the entire scope were 70 .

Coordination between different designers through BIM models prior to construction improved the process and reduced variability at the time of execution. The RFI'S related to plumbing works reduced from 10 to 3 for a particular week i.e. almost $70 \%$ reduction.

\subsection{Cost Saving by avoiding core cutting:}

In continuation with the majority of clashes observed in Table 5 for plumbing and structure the cost implication has been mapped for the process. Following the clashes between the pipes and the structural elements, a potential resolution was to provide sleeves at the time of casting the structural elements. However, since the sleeves were not originally designed, if not detected early, the need for core cutting (in the structural elements) would have emerged. Following the clash detection, the major re-routings were identified and cost implication for core cutting was calculated.

The core cutting diameters range from $(102 \mathrm{~mm}-302 \mathrm{~mm})$. The variation amounts for the case study whose diameters are $(102 \mathrm{and} 127 \mathrm{~mm})$ are Rs 4,060 ( \$ 62.26) and Rs 4,751 ( $\sim 72.86)$. Similarly the cost was calculated for diameters $152,202,302 \mathrm{~mm}$ core cuts whose variation amount came to Rs 10, $134(\sim$ 155.35), Rs 11, 287 ( \$ 173.03) , Rs 9, $920(\sim \$ 152.07)$ and Rs 21, $488(\sim$ 329.41).

The cost variation report was generated which gave information about savings that was around Rs.61, 640 ( $\sim 944.94)$. with approximate time of 1 week for 50 core cuts as 
per clashes. For the entire scope of the project the cost would have rose to Rs.6,16,400 $(\sim 9,449.41)$ with 500 corecuts.

\section{One month look ahead Schedule:}

A four week look ahead schedule helped to monitor in advance the challenges that would be faced in the coming month at the time of execution and tried to solve them to save cost and time overruns. The look ahead schedule integrated with BIM tackled two distinct challenges, that of visualization of plan and detailed production planning including resource allocation and commitment management in general.

The activities that will happen in the month of August'17 were pulled from the Master Schedule as shown in Table 6. The main activities related to: Column, Slab, Beam, Blockwork and Staircase were worked upon zone wise. All these zones were defined at the initial look-ahead stages for which the major challenges were identified. It gave major quantum of weekly work planning.

The look ahead schedule helped in the process of solving constructability issues. The input flows such as quantum of work, quantity of material and drawings required for the coming month were identified by adopting this look ahead schedule.

If this process would not have been adopted the issue of constructability would not have been resolved as the same schedule was linked with the BIM model that helped to visualise the process. The duration of activities was reduced from 358 days to 230 days with cost saving of Rs 5, 40,000 ( \$ 8,278.20) in terms of shuttering material. So it acted as a step for $4 \mathrm{D}$ simulation and simultaneously for production planning.

Table 6 One month Look ahead (partially shown)

\begin{tabular}{|c|c|c|c|c|c|c|c|c|c|}
\hline \multirow[b]{2}{*}{$\begin{array}{l}\text { S } \\
\text { r. } \\
\text { n } \\
\text { o }\end{array}$} & \multicolumn{9}{|c|}{ Work plan for next four weeks } \\
\hline & $\begin{array}{l}\text { Activity } \\
\text { descripti } \\
\text { on }\end{array}$ & Area & UOM & $\begin{array}{c}\text { Total } \\
\text { planned }\end{array}$ & Week 1 & $\begin{array}{c}\text { Week } \\
2\end{array}$ & $\begin{array}{c}\text { Week } \\
3\end{array}$ & $\begin{array}{l}\text { We } \\
\text { ek } 4\end{array}$ & $\begin{array}{c}\text { Remar } \\
\text { ks }\end{array}$ \\
\hline 1 & $\begin{array}{c}\text { Tower } \\
\text { area } \\
\text { Slab and } \\
\text { beam }\end{array}$ & $\begin{array}{c}\text { Ground } \\
\text { Floor }\end{array}$ & Cum & 292 & - & 146 & 146 & - & \\
\hline 2 & $\begin{array}{c}\text { Tower } \\
\text { area } \\
\text { Verticals } \\
\text { (Columns } \\
\text { ) }\end{array}$ & $\begin{array}{l}\text { Ground to } \\
\text { 1st floor }\end{array}$ & Cum & 131 & - & - & - & - & $\begin{array}{c}\text { As per } \\
\text { availab } \\
\text { le }\end{array}$ \\
\hline $\begin{array}{l}2 . \\
1\end{array}$ & Zone 1 & $\begin{array}{l}\text { Ground to } \\
\text { 1st floor }\end{array}$ & Cum & - & 49 & - & - & - & $\begin{array}{c}\text { drawin } \\
\text { gs. }\end{array}$ \\
\hline $\begin{array}{l}2 . \\
2\end{array}$ & Zone 2 & $\begin{array}{l}\text { Ground to } \\
\text { 1st floor }\end{array}$ & Cum & - & 32 & - & - & - & \\
\hline $\begin{array}{l}2 . \\
3\end{array}$ & Zone 3 & $\begin{array}{l}\text { Ground to } \\
\text { 1st floor }\end{array}$ & Cum & - & - & 49 & - & - & \\
\hline
\end{tabular}




\section{Constructability through 4D Simulation:}

Constructability through 4D simulation has a link based on clash free model obtained in Table 5 and zoning created for one month look-ahead as shown in Table 6 . The schedule was integrated with BIM and a 4D simulation model was generated. The major activities observed for constructability taken for Ground and First floor were Column, Slab, Beam, Blockwork and Staircase.

The columns were distributed into different zones for 2300.61 sq.mt of floor area i.e. Zone 1(Red), Zone 2(Yellow), and Zone 3(Green). In Zone 1(Red): there were total 15 columns, Zone 2(Yellow): there were total 10 columns and Zone 3(Green): there were total 15 columns. The construction sequence was: 1. Slab and beam 2.Zone 1 Columns 3.Zone 2 Columns 4. Zone3 Columns 5. Staircase 6.Blockwork as shown in Figure 1.This process was repeated for the next floor and was continued till 10th floor. In the above process columns kept on constructing as per the zones starting from Zone1 and ending on Zone 3.

The whole process helped in visualising the activities, their related issues for the coming month and prepare material, labour and drawings ready in advance that will increase the production flow and value when executed.

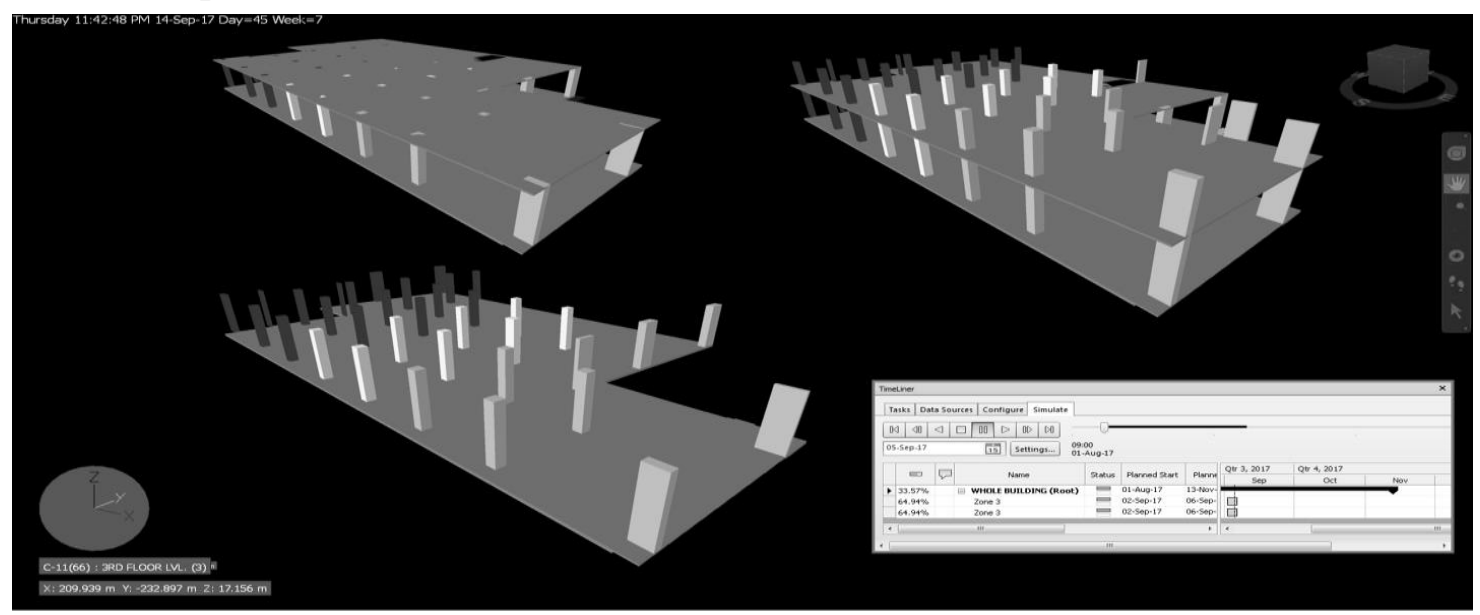

Figure 1 4D Simulation as per linked schedule

\section{DISCUSSION AND CONCLUSION}

The study highlighted that there are several design coordination issues that affect the efficiency of not only the design but also the construction process. Lean and BIM if implemented simultaneously can help resolve these issues, however there are major gaps in research when it comes to real-world examples and how they achieve this integration.

Based on the case study and solutions devised, Table 7 was created to demonstrate the interactions that were achieved between Lean and BIM, based on the original study by (Sacks et al. 2010)but the matrix is achieved for limited interactions more interactions can be worked upon and proved practically, and Table 8 gives the explanations for the indexes mentioned in Table 7 and also elaborates the post implementation process of Lean and BIM integration. 
This research shows that lean and BIM if applied in an integrated way will help resolve coordination issues during design and construction, however the study is limited to a single project in India and more such studies are needed to create a systemic framework in addressing design coordination and construction management related issues.

Table 7 Interaction Matrix of Lean principles and BIM Functionalities

\begin{tabular}{|c|c|c|c|c|}
\hline \multirow[b]{3}{*}{ BIM Functionality } & \multicolumn{4}{|c|}{ Lean Principles } \\
\hline & $\begin{array}{l}\text { Reduce } \\
\text { Variability }\end{array}$ & $\begin{array}{l}\text { Increase } \\
\text { flexibility }\end{array}$ & $\begin{array}{l}\text { Design the } \\
\text { production system } \\
\text { for flow and value }\end{array}$ & $\begin{array}{l}\text { Verify and } \\
\text { Validate }\end{array}$ \\
\hline & $A$ & B & C & D \\
\hline Visualization of form & 1 & & & \\
\hline Reuse of model data for & 1 & & & \\
\hline $\begin{array}{l}\text { predictive analyses } \\
\text { Maintenance of }\end{array}$ & 2 & & & 2 \\
\hline $\begin{array}{l}\text { information and design } \\
\text { model integrity }\end{array}$ & 3 & & & 3 \\
\hline $\begin{array}{l}\text { Collaboration in design } \\
\text { and construction } \\
\text { Rapid generation and }\end{array}$ & 1 & 1 & & \\
\hline $\begin{array}{l}\text { evaluation of multiple } \\
\text { construction plan } \\
\text { alternatives }\end{array}$ & & & 4 & \\
\hline
\end{tabular}

Table 8 Interaction Matrix: Explanation of Cells

\begin{tabular}{|c|c|c|}
\hline \multirow[t]{2}{*}{ Index } & \multicolumn{2}{|c|}{ Explanation } \\
\hline & Pre Implementation & Post Implementation \\
\hline 1. & $\begin{array}{l}\text { Manual clash checking took } 1 \text { week for } \\
\text { an area of } 23791.11 \text { sq.m with still } \\
\text { having manual discrepancies.RFI's } \\
\text { related to plumbing were } 10 \text { for a } \\
\text { particular week. }\end{array}$ & $\begin{array}{l}\text { The incompletely detailed parts were easily } \\
\text { observed in automated clash checking } \\
\text { reducing efforts to a day simultaneously RFI'S } \\
\text { reduction to } 3 \text {, almost } 70 \% \text { reduction. This } \\
\text { improved design quality reducing variations. }\end{array}$ \\
\hline 2 & $\begin{array}{l}\text { Manual quantification of elements for } \\
\text { the entire scope of the project took } 600 \\
\text { minutes including checking for } \\
\text { variations, if any. }\end{array}$ & $\begin{array}{l}\text { The BIM model data used in automated } \\
\text { quantity takeoff taking just } 75 \text { minutes for the } \\
\text { entire scope making work } 88 \% \text { faster. } \\
\text { Quantity variations easily tracked with the } \\
\text { variation amount tending to Rs } 28,17,800 \\
(\sim 43,062.84) \text { for } 100 \& 200 \mathrm{~mm} \text { blockwork } \\
\text { reducing variability at the time of billing. }\end{array}$ \\
\hline 3 & $\begin{array}{l}\text { No verification/validation of designs } \\
\text { before actual execution. }\end{array}$ & $\begin{array}{l}\text { Verification and validation done in terms of } \\
\text { clashes detected related to plumbing saving } \\
\text { against rework cost of Rs.6,16,400 } \\
(\sim \$ 9,449.41) \text { for } 500 \text { core cuts for the entire } \\
\text { scope. }\end{array}$ \\
\hline 4 & $\begin{array}{l}\text { No future thoughts for designing } \\
\text { production system for flow, value and } \\
\text { any generation r of } \\
\text { alternatives/visualization for reducing } \\
\text { coordination issues. }\end{array}$ & $\begin{array}{l}4 \mathrm{D} \text { and look ahead helped in reducing issues } \\
\text { during production. The duration for the } \\
\text { activities was reduced from } 358 \text { days to } 230 \\
\text { days. Cost saving for the shuttering material } \\
\text { due to zone wise planning came to Rs } 5 \text {, } \\
40,000(\sim \$ 8,278.20) \text {. }\end{array}$ \\
\hline
\end{tabular}




\section{REFERENCES}

Alarcon, L.F. \& Mardones, D.A. (1998). "Improving the Design-Construction Interface" Proc of the.6th Ann. Conf. of the Int'l. Group for Lean Construction. Guarujá, Brazil

Ashwin Mahalingam, Amit Kumar Yadav and Jarjana Varaprasad (2015). "Investigating the Role of Lean Practices in Enabling BIM Adoption: Evidence from Two Indian Cases" J. Constr. Eng. Manage., 10.1061/ (ASCE) CO.1943-7862.0000982, 141(7):05015006, 1-11

Eastman C., Teicholz P., Sacks R., Liston K. (2008). “Camino Medical Group Mountain View Medical Office Building Complex in Chapter 9" BIM Case Studies - BIM Handbook - A guide to Building Information Modeling for Owners, Managers, Designers, Engineers, and Contractors, John Wiley \& Sons,358-374

Ergo Pikas, Lauri Koskela, Bhargav Dave, Roode Liias (2015). "Case Study on Design Management: Inefficiencies and Possible Remedies" Proc of the.23rd Ann. Conf. of the Int'l. Group for Lean Construction. Perth, Australia

Fischer, Martin, Maureen Stone, Kathleen Liston, John Kunz, and Vibha Singhal (2002): "Multi-stakeholder collaboration: The CIFE iRoom" In Proceedings of the CIB W78 Conference, Distributing Knowledge in Building, Aarhus, Denmark,12-14

J. Won, G. Lee (2016), "How to tell if a BIM project is successful: a goal-driven approach"Autom. Constr., 34-43.

Korman T.M., Fischer, Martin and Tatum C.B. (2003) "Knowledge and Reasoning for MEP Coordination” J. Constr. Eng. Manage, Volume 129, Issue 6, 627-634.

Leonardo Rischmoller, Luis F.Alarcon and Lauri Koskela (2006). "Improving Value Generation in the Design Process of Industrial Projects Using CAVT" J. Constr. Eng. Manage., 10.1061/ (ASCE) 0742-597X (2006)22:2(52)

Maier, A. M., \& Storrle, H. (2011) "What Are the Characteristics of Engineering Design Processes?" International Conference on Engineering Design, ICED11, Denmark.

Malak Al Hattab, Farook Hamzeh (2016). "Modeling Design Workflow: Integrating Process and Organization" Proc. 24th Ann. Conf. of the Int'1. Group for Lean Construction. Boston, MA, USA

Matti Tauriainen, Pasi Marttinen, Bhargav Dave, Lauri Koskela (2016). "BIM and Lean Construction Change Design Management Practices"Creative Construction Conference, 668-673

Reza Tabesh, A \& Staub-French, Sheryl. (2006) "Modeling and coordinating building systems in three dimensions: A case study" Canadian Journal of Civil Engineering -. 33. 1490-1504. 10.1139/L06-124.

R.Sacks, Lauri Koskela, Bhargav A. Dave and Robert Owen (2010). "Interaction of Lean and Building Information Modeling in Construction" J. Constr. Eng. Manage., 10.1061/ (ASCE) CO1943-7862.0000203, 136(9), 968-980

S.A. Jones, H.M. Bernstein (2012), "The business value of BIM in North America: multiyear trend analysis and user ratings" McGraw-Hill Construction Bedford, MA

Sarmad Mehrbod, Sheryl Staub-French, Melanie Tory, Narges Mahyar (2015) "A Framework For Classifying BIM Design Coordination Issues" 5th International/11th Construction Specialty Conference, 329-1-329-10 
Tatum C.B. and Korman T.M. (2000) "Coordinating building systems: process and knowledge" Journal of Architectural Engineering, 6(4), 116-121.

Tribelsky, E. and Sacks, R. (2011) "An Empirical Study of Information Flow in Multidisciplinary Civil Engineering Design Teams Using Lean Measures" Architectural Engineering and Design Management, 85-101.

V. Peansupap, R. Ly (2015) "Evaluating the impact level of design errors in structural and other building components in building construction projects in Cambodia" Protein Eng. 123 370-378

Wang, B., Li, H., Rezgui, Y., Bradley, A., Ong, H. N. (2014) "BIM Based Virtual Environment for Fire Emergency Evacuation" The Scientific World Journal, 2014, 22 p. 